\title{
Physical characteristics of fruit of yellow passion fruit produced in soil with bio-fertilizer, mulching and saline water
}

\author{
Características físicas de los frutos del maracuyá amarillo producido \\ en suelo con biofertilizante, mantillo y agua salina
}

\author{
José Lucínio de Oliveira Freire ${ }^{1}$, Lourival Ferreira Cavalcante ${ }^{2}$, Alex Matheus Rebequi ${ }^{2 *}$, \\ Thiago Jardelino Dias ${ }^{2}$, Míriam Alice da Silva Brehm², Joao Batista dos Santos ${ }^{3}$
}

\begin{abstract}
The size and yield of fruit are important in the physical quality of the fruits destined for markets and industry. An experiment was performed to evaluate the form, peel strength and yield of fruits of yellow passion fruit plant produced in substrata with bovine bio-fertilizer and mulching, irrigated with saline water. The treatments were designed in three random blocks using a $2 \times 2 \times 2$ factorial arrangement; irrigation with non-saline $\left(0.50 \mathrm{dS} \mathrm{m}^{-1}\right)$ and saline $\left(4.50 \mathrm{dS} \mathrm{m}^{-1}\right)$ water, with and without application of bovine biofertilizer and with and without mulching. The passion fruit fruits were harvested when $30 \%$ of the peel was yellowish; we evaluated the diameter of the longitudinal cavity (length), diameter of the equatorial cavity (width), fruit form index, peel strength and juice and pulp yield. The substrate with bovine bio-fertilizer and mulching irrigated with high salinity water reduced the diameter of the longitudinal and equatorial cavity, the fruit form index and increased the firmness of the peel of the fruits of the yellow passion fruit plant. However, the use of the bovine biofertilizer and mulching irrigated with non-saline water increased the diameter of the equatorial and longitudinal cavity and the fruit form index.
\end{abstract}

Key words: Passiflora edulis, quality of fruit, salinity, organic input.

\section{RESUMEN}

Las dimensiones y el rendimiento de los frutos son características fundamentales para la calidad de frutos destinados al mercado y la industria. En este sentido se realizó un experimento para evaluar el formato, resistencia y rendimiento de maracuyá amarillo producido en sustrato con biofertilizante bovino, mantillo e irrigado con agua salina. El diseño experimental fue de

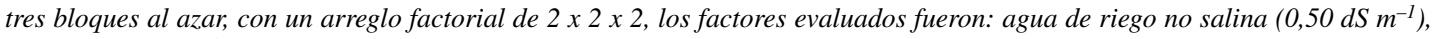

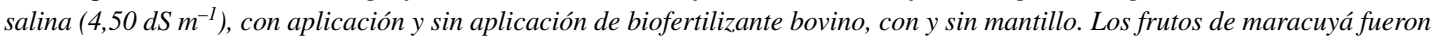
cosechados con $30 \%$ de corteza amarillenta y se evaluó el diámetro de la cavidad longitudinal (largura), diámetro de la cavidad ecuatorial (transversal), índice de formato de los frutos, resistencia de la cáscara y rendimiento de jugo y pulpa. Los mayores valores de diámetro de la cavidad longitudinal, diámetro de la cavidad ecuatorial, índice de formato de los frutos y rendimiento de jugo y pulpa se obtuvieron con el uso de biofertilizante bovino y mantillo en los sustratos regados con agua de alto nivel de salinidad. El uso de agua de alto nivel de salinidad redujo el diámetro de la cavidad longitudinal, el diámetro de la cavidad ecuatorial, el índice de formato de los frutos, independientemente de la presencia de insumos orgánicos en el sustrato y aumentó el rendimiento de jugo, pulpa y resistencia de la cáscara en los tratamientos sin biofertilizante y sin mantillo. El mayor índice de formato del fruto presentó el mayor rendimiento de jugo.

Palabras clave: Passiflora edulis L., calidad del fruto, salinidad, insumos orgánicos.

\section{Introduction}

Yellow passion fruit is native to tropical America; it is grown and processed in all countries of the world. In Brazil it is grown from north to south, with a total production of 614,000 $t$ of fruit in an area of 45,300 ha
(Agrianual, 2009). The northeast region is the greatest producer (Vianna-Silva et al., 2008); production is destined to the preparation of frozen juice concentrate and fresh consumption (Santos et al., 2009).

One of the concerns of the producers of this fruit in the northeast region of Brazil is to produce quality

\footnotetext{
Instituto Federal de Educação, Ciência e Tecnologia da Paraíba.

Universidade Federal da Paraíba.

Universidade Federal de Campina Grande.

* Corresponding author: lofeca@cca.ufpb.br
}

Fecha de Recepción: 17 Mayo, 2012.

Fecha de Aceptación: 2 Octubre, 2013. 
fruit of passion fruit using the natural resources available in the region, which is fundamental to foment regional development and the generation of jobs and income in the field (Pimentel et al., 2009). Most of the crops grown in the northeast region of the country suffer water stress during the growth and development of the plants. In the case of yellow passion fruit, water deficit during the production phase may lead to a decrease in fruit weight and pulp volume, wilt and finally fruit fall (Teixeira et al., 1990), affecting productivity in mean weight, length and diameter of the fruit (Cavichioli et al., 2008).

In addition to the water deficit, the northeast region must face salinity, usually due to the high evapotranspiration demand, reduced precipitation and poor management of drainage (Silva et al., 2009). According to Ayers \& Westcot (1999), yellow passion fruit is highly sensitive to the action of salts; irrigation with saline water may produce undesired effects in the physicochemical quality of the fruit (Costa et al., 2001; Freire et al., 2010; Dias et al., 2011).

The fruit form index is important in classification and standardizing; it affects the acceptance and judgment of the product in some markets (Purquerio \& Cecilio Filho, 2005). For fresh consumption, yellow passion fruit is classified by size (Meletti, 2001) and external aspect (Hafle et al., 2009), given that consumers prefer oval fruits (Oliveira et al., 2008) with an attractive aspect which are sweeter and less acid (Cavichioli et al., 2008), as well as uniform color, resistance to transport and useful post-harvest life which satisfies market standards (Vianna-Silva et al., 2008).

Recent research using organic products such as bovine bio-fertilizer and mulch in the soil has shown promising results, finding significant increases in yield in most crops irrigated with saline water (Campos et al., 2007; Freire et al., 2010; Freire et al.; 2011; Davis et al., 2011; Campos et al., 2011a; Campos et al., 2011b). Thus the purpose of this study was to evaluate the physical attributes of yellow passion fruit irrigated with low and high salinity in substrate with bovine bio-fertilizer and mulch.

\section{Materials and Methods}

The study was performed between September, 2009 and April, 2010, using pressure lysimeters installed in the experimental field of Remigio $\left(6^{\circ} 53^{\prime} 00^{\prime \prime} \mathrm{S}, 36^{\circ} 02^{\prime} 00^{\prime \prime} \mathrm{W}\right)$, in the agricultural area of the Estate of Paraiba, Brazil. The climate is warm and humid; during the study period precipitation was $166 \mathrm{~mm}$ and the mean air temperature oscillated from $25^{\circ} \mathrm{C}$ to $28^{\circ} \mathrm{C}$.

Pressure lysimeters were constructed in plastic recipients with substrate capacity of $130 \mathrm{dm}^{3}(60 \mathrm{~cm}$ diameter $\times 50 \mathrm{~cm}$ height) installed with a separation of $3.0 \times 3.0 \mathrm{~m}$ over a brick platform $30 \mathrm{~cm}$ above soil level. Two equidistant $1 \mathrm{~cm}$ diameter drainage holes were perforated in the internal base of each to collected drained solution. To avoid clogging of the holes a $2.5 \mathrm{~cm}$ layer of gravel was placed first, covered by a $5 \mathrm{~cm}$ layer of sand; the remainder was substrate. The substrate consisted of a mixture of soil removed from the top $10 \mathrm{~cm}$ of a eutrophic yellow ultisol (Santos et al., 2006), with bovine feces $(\mathrm{C} / \mathrm{N}$ ratio $16 / 1$ and $12 \%$ humidity) in 10:1 volumetric proportion. The substrate was analyzed using the methodology proposed by Embrapa (2011), showing the following physical attributes: sand, silt, clay and clay dispersed in water $=28,106.66$ and $26 \mathrm{~g} \mathrm{~kg}^{-1}$; degree of flocculence and dispersion index $=60.6 \%$ and $39.9 \%$; soil and particle densities 1.26 and $2.73 \mathrm{~g} \mathrm{~cm}^{-3}$; total porosity $=0.54 \mathrm{~m}^{3} \mathrm{~m}^{-3}$; soil humidity at $0.033 \mathrm{MPa}, 0.1 \mathrm{MPa}, 1.0 \mathrm{MPa}$ and 1.5 $\mathrm{MPa}=103,82.8,55.4$ and $30.7 \mathrm{~g} \mathrm{~kg}^{-1}$, respectively; $\mathrm{Na}^{+}, \mathrm{Ca}^{2+}, \mathrm{Mg}^{2+}, \mathrm{H}^{+}+\mathrm{Al}^{3+}, \mathrm{CIC}_{\mathrm{pH} 7.0}=0.29,3.95$, $1.10,1.65$ and $7.30 \mathrm{cmolc} \mathrm{dm}^{-3}$ respectively; base saturation $=77.4 \%$ and $\mathrm{MO}=11.8 \mathrm{~g} \mathrm{~kg}^{-1}$.

Treatments consisted of two levels of electrical conductivity (EC) of irrigation water (non-saline $\mathrm{EC}=0.50 \mathrm{dS} \mathrm{m}^{-1}$ and saline water $\mathrm{EC}=4.50 \mathrm{dS}$ $\mathrm{m}^{-1}$ ), with and without application of bovine biofertilizer and with and without mulch in a $2 \times 2$ x 2 factorial arrangement, using three repetitions and three plants per experimental unit. The less saline water came from a superficial source in the experimental area; this was also used to dilute highly saline water $\left(\mathrm{EC}=9.50 \mathrm{dS} \mathrm{m}^{-1}\right)$ to obtain the experimental EC of $4.50 \mathrm{dS} \mathrm{m}^{-1}$. Plants were watered daily with $20 \%$ of the water layer evaporated during the previous day, measured in a class A tank installed beside the experimental zone.

The bovine bio-fertilizer was obtained by anaerobic fermentation of fresh cow feces mixed $1: 1$ with water without chlorine and left in a hermetically sealed container for at least 30 days (Santos \& Akiba, 1996). The methane gas produced in the fermentation was liberated by means of a hose connected to the top of the biodigester; the other end 
of the hose was submerged in water to impede air entrance. Each lysimeter received $10 \mathrm{dm}^{3}$ of bovine bio-fertilizer diluted 1:1 with water and applied to the surface of the substrate, one week before and every 90 days after transplanting until the end of the experiment, as suggested by Cavalcante $e t$ al., (2007). The analytical measurements of the salinity of the diluted bovine bio-fertilizer and irrigation water using the methods of Richards (1954) and Embrapa (2011) are given in Table 1. Bermuda grass (Cynodon dactylon L.) was used for mulch after drying at environmental temperature; $10 \mathrm{~cm}$ layer was placed on the substrate surface. Mulch was replaced every two months.

Plantlets of yellow passion fruit were produced in polyethylene bags ( $18 \mathrm{~cm}$ height, $13 \mathrm{~cm}$ diameter and transplanted to the pressure lysimeters in September, 2009. After careful study, plants $30 \mathrm{~cm}$ tall with 5 pairs of leaves were chosen. Before application of bovine bio-fertilizer and planting, the substrate in each lysimeter was fertilized with $150 \mathrm{~g}$ of simple superphosphate $\left(20 \% \mathrm{P}_{2} \mathrm{O}_{5}\right)$.

Substrates were watered 21 days after transplant (DAT) to saturation with their treatment solutions. At 30 DAT $10 \mathrm{~g}$ of fertilizer $(45 \% \mathrm{~N})$ was applied in the top soil level; after this $30 \mathrm{~g}$ fertilizer $(45 \%$ $\mathrm{N})$ and $50 \mathrm{~g}$ potassium chloride $\left(58 \% \mathrm{~K}_{2} \mathrm{O}\right)$ per plant was applied monthly. When flowering began, $50 \mathrm{~g}$ simple superphosphate per plant was applied.

Yellow passion fruit plants were trained in vertical trellises with smooth $\mathrm{N}^{\circ} 12$ galvanized wire at $2.30 \mathrm{~m}$ above the soil surface, tied and stretched to posts of black wood separated by 3 $\mathrm{m}$. Plants were tied during growth with cord (or String) of sisal to guide the stems to the trellises; ties were loose to avoid strangulation of the stems when they thicken. Tips were clipped when the stem main reached $10 \mathrm{~cm}$ above the high part of the trellis and also when the secondary branches reached $1.50 \mathrm{~m}$ length. Tips of tertiary branches were trimmed at $0.30 \mathrm{~m}$ above soil level to stimulate budding of lateral buds and produce buds oriented to both sides of the trellis. Once flowering began daily manual pollination was performed with pollen from other plants.

During production, nine fruits with at least $30 \%$ of the skin yellow were collected per treatment. The fruits were shipped in polyethylene trays for analysis of their physical attributes to the Laboratory of Biology and Postharvest Technology. Fruit characters evaluated were longitudinal diameter $(\mathrm{LD})(\mathrm{cm})$ and equatorial diameter $(\mathrm{ED})(\mathrm{cm})$, measured with a digital Vernier caliper; the results were used to calculate the diameters of the longitudinal (LDC) and equatorial (EDC) cavities $(\mathrm{cm})$ :

$$
\begin{gathered}
\mathrm{LDC}=[(\mathrm{LD})-(\mathrm{CE} * 2) / 10] \\
\mathrm{EDC}=[(\mathrm{EC})-(\mathrm{EC} * 2) / 10]
\end{gathered}
$$

where LDC $=$ longitudinal diameter of the fruit cavity $(\mathrm{cm}), \mathrm{EDC}=$ equatorial diameter of the fruit cavity $(\mathrm{cm})$ and $\mathrm{EC}$ is the thickness of the peel $(\mathrm{mm})$.

The fruit form index (FFI) is a relation between the longitudinal and equatorial diameters of the fruit. The peel strength (PS) was measured with a Mc Cornick FT 327 ® penetrometer with $8 \mathrm{~mm}$ diameter tip; finally the pulp yield (PY) and juice yield (JY) were measured by the percentage relation between the pulp and juice mass and the fruit mass.

Table 1. Saline characteristics of the bovine bio-fertilizer and irrigation water.

\begin{tabular}{lccc}
\hline Characteristic & Bio-fertilizizer & Non-saline water & Saline water \\
\hline $\mathrm{pH}$ & 6.7 & 6.4 & 7.7 \\
$\mathrm{EC}\left(\mathrm{dS} \mathrm{m}^{-1} \mathrm{a} 25^{\circ} \mathrm{C}\right)$ & 2.55 & 0.50 & 4.50 \\
$\mathrm{RAS}\left(\mathrm{mmol} \mathrm{L}^{-1}\right)$ & 0.87 & 2.12 & 0.57 \\
$\mathrm{Ca}^{2+}\left(\mathrm{mmol}_{\mathrm{c}} \mathrm{L}^{-1}\right)$ & 13.7 & 1.67 & 2.80 \\
$\mathrm{Mg}^{2+}\left(\mathrm{mmol}_{\mathrm{c}} \mathrm{L}^{-1}\right)$ & 17.5 & 0.81 & 8.90 \\
$\mathrm{~K}^{+}\left(\mathrm{mmol}_{\mathrm{c}} \mathrm{L}^{-1}\right)$ & 3.33 & 0.11 & 0.43 \\
$\mathrm{Na}^{+}\left(\mathrm{mmol}_{\mathrm{c}} \mathrm{L}^{-1}\right)$ & 3.42 & 2.37 & 32.0 \\
$\mathrm{SO}_{4}{ }^{2-}\left(\mathrm{mmol}_{\mathrm{c}} \mathrm{L}^{-1}\right)$ & 20.9 & 0.86 & 0.26 \\
$\mathrm{CO}_{3}^{2-}\left(\mathrm{mmol}_{\mathrm{c}} \mathrm{L}^{-1}\right)$ & $<\mathrm{UDL}$ & $<\mathrm{UDL}$ & 0.10 \\
$\mathrm{HCO}^{3-}\left(\mathrm{mmol}_{\mathrm{c}} \mathrm{L}^{-1}\right)$ & 2.50 & 112 & 3.20 \\
$\mathrm{Cl}^{-}\left(\mathrm{mmol}_{\mathrm{c}} \mathrm{L}^{-1}\right)$ & 10.0 & 3.14 & 40.8 \\
$\mathrm{Classification}$ & $\mathrm{C}_{4} \mathrm{~S}_{1}$ & $\mathrm{C}_{1} \mathrm{~S}_{1}$ & $\mathrm{C}_{4} \mathrm{~S}_{1}$ \\
\hline
\end{tabular}

EC - Electrical conductivity; RAS - Sodium absorption ratio $\left[\mathrm{Na}^{+} /\left(\mathrm{Ca}^{2+}+\mathrm{Mg}^{2+} / 2\right)^{1 / 2}\right]$; UDL - Under detection limit. 
Results were interpreted by a factorial analysis of variance with Tukey a posteriori tests using an error rate of 5\%, according to Banzatto \& Kronka (2006).

\section{Results and Discussion}

Fruits of the yellow passion fruit grew more in length than in width (Figures 1 and 2). This is the preferred fruit form for the national consumer market (Oliveira et al., 2008). LDC was less in plants irrigated with saline water, independent of the presence of bovine bio-fertilizer or mulch (Figure 1A, 1B). With less saline water, bio-fertilizer in the soil produced fruits with LDC 9.9\% greater than those without fertilizer. In plants irrigated with saline water, bovine-biofertilizer produced fruits with $20 \%$ greater LDC (Figure 1A).

The fruits of the plants irrigated with more saline water, with and without mulch, reduced their LDC values by $0.7 \mathrm{~cm}$ and $1.4 \mathrm{~cm}$, respectively, compared to those irrigated with less saline water (Figure 1B). These results were generally greater than those reported by Costa et al. (2001) and Freire et al. (2010) for plants irrigated with highly saline water, compared to the poorer results obtained by Campos et al. (2007), who evaluated fruit length of yellow passion fruit with bovine bio-fertilizer and mulch.

EDC values ranged from 5.2 to $5.9 \mathrm{~cm}$. More saline water reduced the EDC by $0.7 \mathrm{~cm}$ in the fruit of plants with soil protected by mulch (Figure 2). The largest mean fruit EDC values are in class 2
( $\geq 55$ to $<65 \mathrm{~mm}$ ) of the commercial fruit quality standards of the Brazilian program for improvement of commercial standards and packing of fruit and vegetable producers (Brasil, 2003), that is, in the optimum class, because according to Oliveira et al (2008) fruit for industry processing must have a significant internal cavity to increase the yield of pulp and juice.

Rodrigues et al., (2008), who studied yellow passion fruit treated with bio-fertilizer of natural mineral salts and Freire et al. (2010), who studied the effict of water salinity on the quality of yellow passion fruit fruits with bovine bio-fertilizer, both reported EDC values greater than those found in this study.

FFI values varied from 1.09 in fruits of plants with high salinity irrigation, without bio-fertilizer and with mulch, to 1.29 in plants irrigated with low saline water, with bio-fertilizer and without mulch (Figure 3). According to Fortaleza et al. (2005) and Farias et al. (2007), greater FFI is associated with more oval fruit; Oliveira et al., (2008) reported that this type of fruit is more requested by the fresh fruit market and the processing industry, since it produces nearly $10 \%$ more juice than round fruits, although the latter are preferred by external markets (Salomão et al., 2001). More saline water reduced the FFI, independently of the addition of organic material and soil cover.

In plants irrigated with non-saline water, the application of bovind bio-fertilizer increased the juice yield (JY) from $35.9 \%$ to $45.0 \%$, an increase of $25.5 \%$, and increased pulp yield (PY) by $21 \%$.
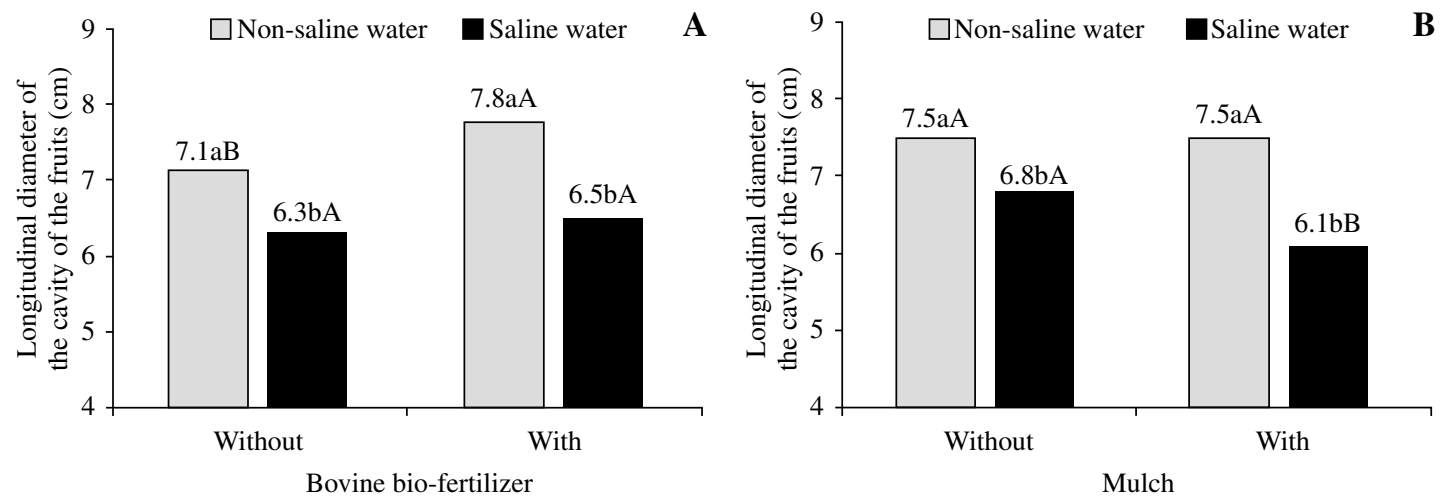

Figure 1. Longitudinal diameter of the cavity (LDC) of the fruits of yellow passion fruit produced in soil with and without bovine bio-fertilizer (A), with and without mulch (B) irrigated with greater and lower salt content. Means followed by the same lower case letter between salinity conditions in the same fertilizer condition, and upper case letters in the same salinity conditions but different fertilizer condition, are not statistically different by the $\mathrm{F}$ test $(\mathrm{P} \leq 0.05)$. 


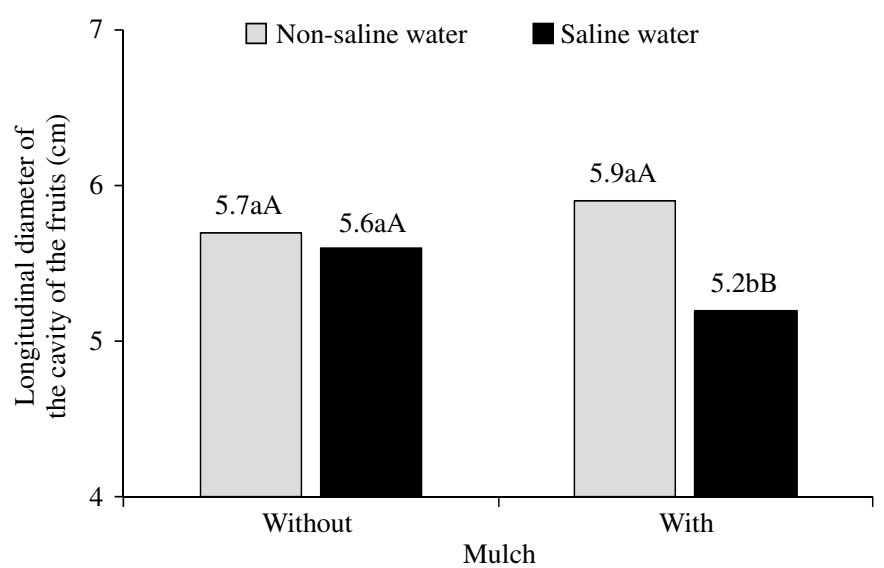

Figure 2. Equatorial diameter of the cavity (EDC) of yellow passion fruit produced in soil with and without bovine bio-fertilizer (A), with and without mulch (B) irrigated with greater and lower salt content. Means followed by the same lower case letter between salinity conditions in the same fertilizer condition, and upper case letters in the same salinity conditions but different fertilizer condition, are not statistically different by the $\mathrm{F}$ test $(\mathrm{P} \leq 0.05)$.

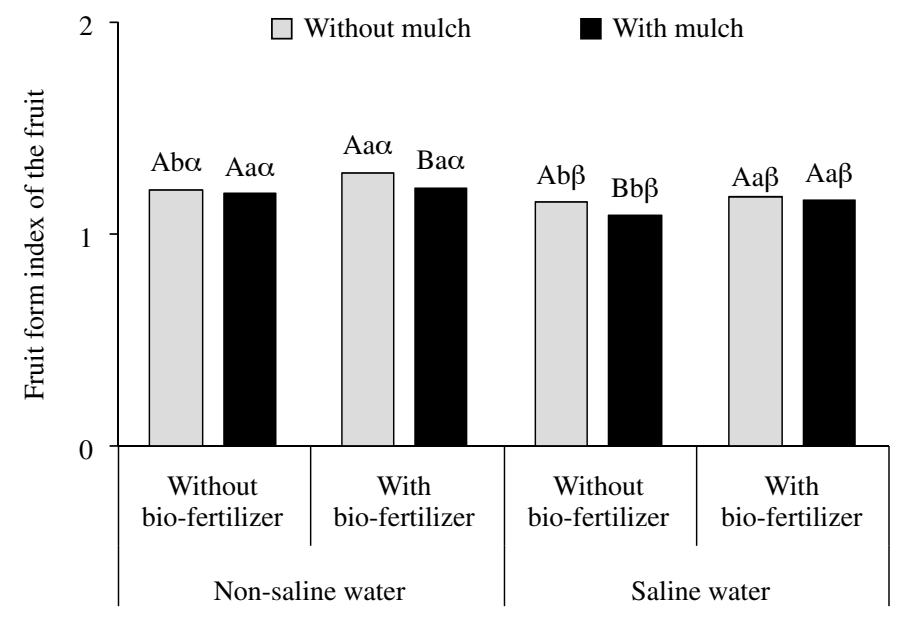

Figure 3. Fruit form index (FFI) of the fruits of yellow passion fruit produced in soil with and without bovine bio-fertilizer (A), with and without mulch (B) irrigated with greater and lower salt content. Means followed by the same lower case letter between salinity conditions in the same fertilizer condition, and upper case letters in the same salinity conditions but different fertilizer condition, are not statistically different by the $\mathrm{F}$ test $(\mathrm{P} \leq 0.05)$.

Irrigation with saline water without bio-fertilizer increased juice and pulp yield by $19 \%$ and $16 \%$, respectively. The use of soil cover increased juice yield from $38.8 \%$ to $42.1 \%(+8 \%)$ and pulp yield from $43.6 \%$ to $46.3 \%(+6 \%)$ in fruits of plants irrigated with non-saline water. However, the use of mulch reduced juice and pulp yield, the latter by $14 \%$ in plants irrigated with saline water (Table 2).

Similar effects were found on juice and pulp yield with bovine bio-fertilizer by Dias et al. (2011). According to the literature, the use of bovine biofertilizers in soil irrigated with saline water produces an increase in the growth and production of crops, because they have organic solutes such as sugars, free amino acids and proline which increase the capacity of plants to adapt to the action of salts (Nardi et al., 2002; Baalousha et al., 2006), while in the absence of such fertilizer growth is quite reduced as a result of the toxic effect of the salts (Freire et al., 2010; Dias et al., 2011).

Overall, $49.2 \%$ of the PR in the treatments with bio-fertilizer irrigated with non-saline water and $49.3 \%$ of the treatments without mulch irrigated with saline water (Table 2) are compatible with the 
Table 2. Juice and fruit pulp yield of the fruits of yellow passion fruit produced in soil with and without bovine bio-fertilizer (A), with and without mulch (B) irrigated with greater and lower salt content.

\begin{tabular}{|c|c|c|c|c|}
\hline \multirow{2}{*}{ Water quality } & \multicolumn{2}{|c|}{ Bovine bio-fertilizer } & \multicolumn{2}{|c|}{ Mulch } \\
\hline & Without & With & Without & With \\
\hline & \multicolumn{4}{|c|}{ Juice yield (JY) } \\
\hline Non-saline water & $35.9 \mathrm{bB}$ & $45.0 \mathrm{aA}$ & $38.8 \mathrm{bA}$ & $42.1 \mathrm{aA}$ \\
\hline Saline water & $42.6 \mathrm{aA}$ & $39.7 \mathrm{aA}$ & $43.9 \mathrm{aA}$ & $38.4 \mathrm{aB}$ \\
\hline \multicolumn{5}{|c|}{ Pulp yield (PY) } \\
\hline Non-saline water & $40.6 \mathrm{bB}$ & $49.2 \mathrm{aA}$ & $43.6 \mathrm{bA}$ & $46.3 \mathrm{aA}$ \\
\hline Saline water & $47.1 \mathrm{aA}$ & $44.7 \mathrm{bA}$ & $49.3 \mathrm{aA}$ & $42.5 \mathrm{aB}$ \\
\hline
\end{tabular}

Means followed by the same lower case letter in columns between salinity conditions in the same fertilizer and mulch condition, and upper case letters in rows, in the same salinity conditions but different fertilizer and/or mulch condition, are not statistically different by the $\mathrm{F}$ test $(\mathrm{P} \leq 0.05)$.

exigencies of the consumer market (50\% PR) (Meletti et al., 2002), while the mean percentage of JY was above the required yield of 33\% (Haendler, 1965) and is also adequate for industry, which prefers fruit with high juice yield (Cavichioli et al., 2008). This high JY may come from yellow passion fruits with a greater number of seeds due to the mucilagenous membrane (sarcotesta) which surrounds each seed.

The peel strength (PS) of the fruit (Figure 4) varied from 96.5 to 101.7 Newtons $(\mathrm{N})$ in the fruits of plants irrigated with non-saline water and from 100.7 to 111.0 in treatments with saline water. These values are greater than those obtained by Rodrigues et al., (2008) in treatments with bio-fertilizer based on natural mineral salts and organic compounds.
Except for the treatments with bio-fertilizer and without mulch (with saline and non-saline water), the other treatments showed an increase in PS in plants irrigated with saline water, which was greatest in the fruit of the treatment with bio-fertilizer and mulch. A greater PS value was also found in the treatment with bio-fertilizer and mulch with nonsaline compared to the treatment without bovine bio-fertilizer, with mulch and non-saline water. This suggests that the increase in salt concentration in the water with higher ionic content associated with the presence of the organic solutes of bio-fertilizer due to greater calcium content produced more calcium pectate in the epicarpal cell wall of the fruits, with a consequent increase in peel strength (Rodrigues

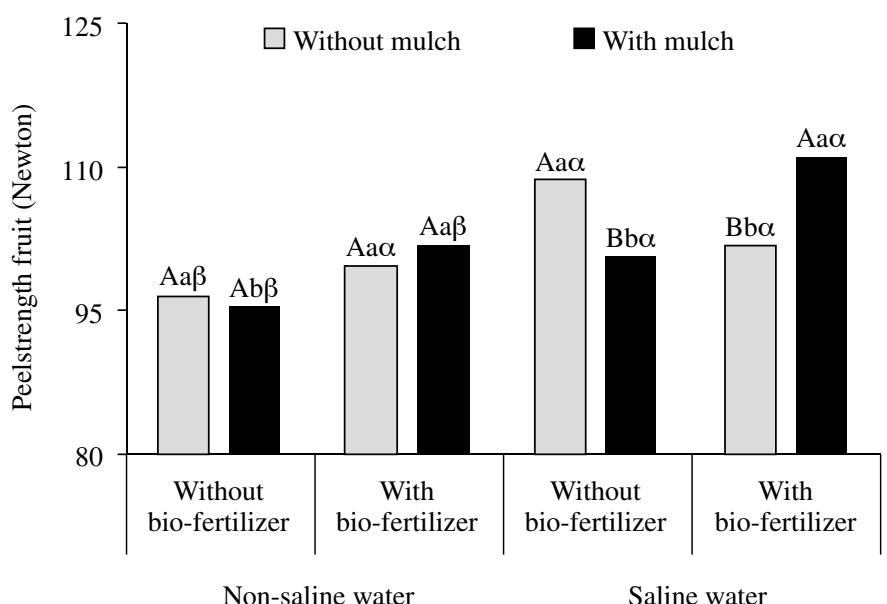

Figure 4. Peel strength (PS) of the fruits in yellow passion fruit watered with non-saline and saline water, in substrate with and without bovine-bio-fertilizer, and with and without mulch. Capital letters compare mulch with the same conditions of water salinity and use of bio-fertilizer; lower case letters compare bovine bio-fertilizer in the same conditions of water salinity and mulch; Greek letters compare water salinity under the same conditions of bovine bio-fertilizer and mulch. Means followed by the same letter are not statistically different ( $\mathrm{F}$ test, $\mathrm{P} \leq 0.05)$. 
et al., 2008), which resulted in greater resistance to transport and longer post-harvest useful life (Vianna-Silva et al. 2008).

According to Lima \& Yamanishi (2012), 74\% of consumers observe the PS of the fruit before buying. This is one of the methods the consumer uses to determine the ripeness and conservation state of the fruit and thus not be fooled when buying the product.

\section{Conclusions}

The greatest values of the longitudinal cavity diameter (LDC) and the equatorial cavity diameter
(EDC), fruit form index (FFI), juice yield (JY) and pulp yield (PY) were obtained with the use of bovine bio-fertilizer and mulch in the substrates irrigated with non-saline water.

The use of non-saline water reduced the longitudinal cavity diameter (LDC), equatorial cavity diameter (EDC) and the fruit form index (FFI) independent of the presence of organic additives in the substrate and increased the juice yield (JY), pulp yield (PY) and peel strength (PS) in the treatments without bio-fertilizer or mulch.

The yellow passion fruit with greatest fruit form index (FFI) showed the best juice yield (JY).

\section{Literature Cited}

Agrianual

2009. Anuário da Agricultura Brasileira. IFNP: São Paulo.

Ayers, R.S.; Westcot, D.W.

1999. A qualidade da água na agricultura. Campina Grande:

UFPB, pp. 1-158, (FAO: Drainage paper, 29).

Baalousha, M.; Motelica-Heino, M.; Coustumer, P.

2006. Conformation and size of humic substances: effects of major cátion concentration and type, $\mathrm{pH}$, salinity, and resistence time. Coloids and Surface A: Physicochemical Engineering Asppects, 272 (1): 48-55.

Banzatto, D.A.; Kronka, S.N.

2006. Experimentação Agrícola. Jaboticabal: FUNEP, 247 pp. Brasil

2003. Ministério da Integração Nacional. Programa Brasileiro Para a Melhoria dos Padrões Comerciais e Embalagens de Horticultura. http://www.integracao.gov.br. 23/11/2003.

Campos, V.B.; Cavalcante, L.F.; Dantas, T.A.G.; Mota, J.K.M.; Rodrigues, A.C.; Diniz, A.A.

2007. Caracterização física e química de frutos de maracujazeiro amarelo sob adubação potássica, biofertilizante e cobertura morta. Revista Brasileira de Produtos Agroindustriais, 9 (1): 59-71.

Campos, V.B.; Cavalcante, L.F.; Prazeres-Campos, S. da S.;

Gheyi, H.R.; Chaves, L.H.G.; Pereira Júnior, L.R.

2011a. Esterco bovino líquido em luvissolo sódico: II. Emergência e análise de crescimento do maracujazeiro amarelo. Idesia, 29 (3): 17-24.

Campos, V.B.; Cavalcante, L. F.; Prazeres-Campos, S. da S.;

Gheyi, H. R.; Chaves, L. H. G.; Mesquita, F. de O.

2011b. Esterco bovino líquido em luvissolo sódico: I. Resposta biométrica e produtiva do maracujazeiro amarelo. Idesia, 29 (2): 59-67.

Cavalcante, L.F.; Santos, G.D.; Oliveira, F.A.; Cavalcante, I.H.L.;

Gondim, S. C.; Cavalcante, M. Z. B.

2007. Crescimento e produção do maracujazeiro amarelo em solo de baixa fertilidade tratado com biofertilizantes líquidos. Revista Brasileira de Ciências Agrárias, 2 (1): 15-19.

Cavichioli, J.C.; Ruggiero, C.; Volpe, C.A.

2008. Caracterização físico-química de frutos de maracujazeiro amarelo submetidos à iluminação artificial, irrigação e sombreamento. Revista Brasileira de Fruticultura, 30 (3): 649-656.
Costa, J.R.M.; Lima, C.A.A.; Lima, E.D.A.; Cavalcante, L.F.; Oliveira, F.K.D.

2001. Caracterização dos frutos de maracujá amarelo irrigados com água salina. Revista Brasileira de Engenharia Agrícola e Ambiental, 5 (1): 143-146.

Dias, T.J.; Cavalcante, L.F.; Freire, J.L. de O.; Nascimento, J.A.M. do.; Beckmann-Cavalcante, M.Z.; Santos, G.P. dos

2011. Qualidade química de frutos do maracujazeiro-amarelo em solo com biofertilizante irrigado com águas salinas. Revista Brasileira de Engenharia Agrícola e Ambiental, 15 (3): 229-236.

Embrapa-Empresa Brasileira de Pesquisa Agropecuária 2011. Manual de Métodos de Análise de Solos. 3 ed. Atualizada. Rio de Janeiro, 230 pp.

Farias, J.F.; Silva, L.J.B.; Araújo Neto, S.E.; Mendonça, V. 2007. Qualidade do maracujá amarelo comercializado em Rio Branco, Acre. Revista Caatinga, 20 (3): 196-202.

Fortaleza, J.M.; Peixoto, J.R.; Junqueira, N.T.V.; Oliveira, A.T.; Rangel, L.E.P.

2005. Características físicas e químicas em nove genótipos de maracujá azedo cultivado sob três níveis de adubação potássica. Revista Brasileira de Fruticultura, 27 (1): 124-127.

Freire, J.L.O.; Cavalcante, L.F.; Rebequi, A.M.; Dias, T.J.; Souto, A.G.L.

2011. Necessidade hídrica do maracujazeiro amarelo cultivado sob estresse salino, biofertilização e cobertura do solo. Revista Caatinga, 24 (1): 82-91.

Freire, J.L.O.; Cavalcante, L.F.; Rebequi, A.M.; Nunes, J.C.; Dias, T.J.; Cavalcante, I.H.L.

2010. Atributos qualitativos do maracujá amarelo produzido com água salina, biofertilizante e cobertura morta no solo. Revista Brasileira de Ciências Agrárias, 5 (1): 102-110.

Haendler, L.

1965. La passiflora: Sa composition chimique et sés possibilités de transformation. Fruits, 20: 235-245.

Hafle, O.M.; Ramos, J.D.; Lima, L.C.O.; Ferreira, E.A.; Melo, P.C. 2009. Produtividade e qualidade de frutos do maracujazeiro amarelo submetido à poda de ramos produtivos. Revista Brasileira de Fruticultura, 31 (3): 763-770.

Lima, M.M; Yamanishi, O.K.

2012. Análise do mercado consumidor de maracujá da RIDE. 21 pp. Disponível em: http://www.sober.org.br/palestra/2/595. pdf. 24/06/2013. 
Medeiros, S.A.F.; Yamanishi, O.K.; Peixoto, J.R.; Pires, M.C.N.; Junqueira, T.V.; Ribeiro, J.G.B.L.

2009. Caracterização físico-química de progênies de maracujá roxo e maracujá amarelo cultivados no Distrito Federal. Revista Brasileira de Fruticultura, 31 (2): 492-499.

Meletti, L.M.M.

2001. A cultura do maracujazeiro em São Paulo. O Agronômico, 53 (1): 18-20.

Meletti, L.M.M.; Soares-Scott, M.D.; Bernacci, L.C.; Azevedo, F.J.A. 2002. Desempenho das cultivares IAC-273 e IAC-277 de maracujazeiro amarelo (Passiflora edulis f. flavicarpa Deg.) em pomares comerciais. In: Reunião Técnica de Pesquisa em Maracujazeiro Amarelo, 3, 2002, Viçosa. Anais...Viçosa: SBF, v. único: 166-167.

Nardi, S.; Pizzeghello, D.; Muscolo, A.; Vianelo, F. 2002. Physiological effects of humic substances on higher plants. Soil Biology \& Biochemistry, 34 (4): 1527-1536.

Oliveira, E.J. de; Santos, V. da S.; Lima, D.S. de; Machado, M.D.; Lucena, R.S.; Motta, T.B.N.; Castellen, M. da S.

2008. Seleção em progênies de maracujazeiro-amarelo com base em índices multivariados. Pesquisa Agropecuária Brasileira, 43: 1543-1549.

Pimentel, L.D.; Santos, C.E.M.; Ferreira, A.C.C.; Martins, A.A.; Wagner Júnior, A.; Bruckner, C.H.

2009. Custo de produção e rentabilidade do maracujazeiro no mercado agroindustrial da Zona da Mata Mineira. Revista Brasileira de Fruticultura, 31: 397-407.

Purquerio, L.F.V.; Cecílio Filho, A.B.

2005. Concentração de nitrogênio na solução nutritiva e número de frutos sobre a qualidade de frutos de melão. Horticultura Brasileira, Brasília, v. 23 (3): 831-836.

Richards, L.A.

1954. Diagnóstico y rehabilitación de suelos salinos y sódicos. Departamento de Agricultura de los Estados Unidos de América, 172 pp.
Rodrigues, A.C.; Cavalcante, L.F.; Dantas, T.A.G.; Campos, V.B.; Diniz, A.A.

2008. Caracterização de frutos de maracujazeiro amarelo em solo tratado com "biofertilizante supermagro" e potássio. Magistra, 20(3): 264-272.

Salomão, L.C.C.; Vieira, G.; Mota, W.F.

2001. Tecnologia de colheita e pós-colheita. In: Bruckner, C.H.; Picanço, M.C. Maracujá: tecnologia de produção, pós-colheita, agroindústria, mercado. Porto Alegre: Cinco Continentes, $472 \mathrm{pp}$.

Santos, A.C.V.; Akiba, F.

1996. Biofertilizante líquido: uso correto na agricultura alternativa. Seropédica: UFRRJ. 35 pp.

Santos, C. E. M. dos; Bruckner, C.H.; Cruz, C.D.; Siqueira, D.L. de; Pimentel, L.D.

2009. Características físicas do maracujá-azedo em função do genótipo e massa do fruto. Revista Brasileira de Fruticultura, 31: 1102-1119.

Santos, H.G.; Jacomine, P.K.T.; Anjos, L.H.C.; Oliveira, V.A.;

Oliveira, J.B.; Coelho, M.R.; Lumbrebas, J.F.; Cunha, T.J.F.

2006. Sistema brasileiro de classificação de solos. 2ed. Rio de Janeiro: Embrapa Solos. 306 pp.

Silva, E.N.; Silveira, J.A.G.; Rodrigues, C.R.F.; Lima, C.S.; Viégas, R.A.

2009. Contribuição de solutos orgânicos e inorgânicos no ajustamento osmótico de pinhão manso submetido à salinidade. Pesquisa Agropecuária Brasileira, 44 (5): 437-445.

Teixeira, D.M.M.; Olitta, A.F.L.; Vasconcelos, L.A.B.C. de 1990. Efeito de vários níveis de fertirrigação na cultura do maracujazeiro-amarelo (Passiflora edulis var. flavicarpa). Engenharia Rural, 1 (1): 1-76.

Vianna-Silva, T.; Resende, E.D.; Viana, A.P.; Pereira, S.M.F.; Almeida Carlos, L.; Vitorazi, L.

2008. Qualidade do suco de maracujá amarelo em diferentes épocas de colheita. Ciência e Tecnologia de Alimentos, 28 (3): 545-550. 